\title{
Disruption of Identity: A Qualitative Exploration of the Existential Experience among Minorities in Post 2017's Jakarta Election
}

\author{
Mokorowu Yanny $^{1 *}$, Saragih Denni Boy ${ }^{1}$, Winoto Hery ${ }^{2}$, and Peranginangin Prasasti ${ }^{1}$ \\ ${ }^{1}$ Center of Character Development, Krida Wacana Christian University, Jl. Tanjung Duren Raya \\ No. 4 Jakarta 11470, Indonesia \\ ${ }^{2}$ Faculty of Economics, Krida Wacana Christian University, Jl. Tanjung Duren Raya No. 4 \\ Jakarta 11470, Indonesia
}

\begin{abstract}
Several distinguished philosophers provide insightful reflections on the meaning of alienation, anxiety, and apathy. This paper elaborates on these notions based on Kierkegaard's idea of anxiety and Marx's idea of alienation in the experience of the supporters of Basuki Tjahaya Purnama (BTP) after his loss in the Jakarta governor election of 2017. The qualitative findings show the result has left a deep impact among his supporters, especially those who share the same background as BTP, namely the Chinese-Christian minority. In their view, the main reason for BTP's loss was the racial and religious smear campaign played out during the election. This led them to a deep disappointment in response to the unexpected turn of events. The findings show that the feelings of the Chinese as second-class citizens in Indonesia have resurfaced. At an existential level, it raises anxiety and alienation that has led to social and political apathy among those who identify themselves as the ChineseChristian minority. The existential impact of the disappointment has led to a feeling of indifference and resignation toward political involvement in future democratic affairs.
\end{abstract}

Keywords: Alienation, anxiety, apathy, Chinese-Christian, minority.

\section{Introduction}

In several surveys, the level of citizen satisfaction with Basuki Tjahaya Purnama's (hereafter BTP) leadership was as high as $70 \%$ [1]. It was shocking news when BTP lost the election, and more so among his supporters. The unexpected result particularly saddened those with a Chinese-Christian background since the integrity and competency of BTP's leadership was a distinct quality among political leaders in Indonesia. He is perceived as an ideal leader who exemplifies the most excellent character that is needed to bring about a real change in Jakarta. The loss of BTP is not seen as the result of a fair election, but instead of a smear campaign based on the accusation of religious blasphemy toward the Muslim community. Racial and religious issues were the main attack in destroying BTP's reputation.

* Corresponding author: yanny.mokorowu@ukrida.ac.id 
The attack on BTP's minority identity impacts profoundly on the feelings of his supporters who share the same background. This research was conducted to explore the experience of Chinese-Christians, i.e., to find the deep feelings or existential experiences they underwent as a result of the election. By using a qualitative interview, this research explores the authentic feelings of Chinese-Christians and how the election changed their self-perception as citizens in the aftermath of the election. This article begins with the design of the research, the qualitative findings, the discussion about anxiety, alienation, and apathy, and finally ends with a reflective conclusion about the Chinese-Christian existential feeling.

\section{Method}

To explore how BTP's supporters experienced and coped with the tension during the gubernatorial campaign and election, a qualitative study using a semi-structured sampling interview has been conducted with five respondents: middle-class workers aged between $30 \mathrm{yr}$ old and $55 \mathrm{yr}$ old from a Chinese-Christian background.

\section{Research design}

The research is an existential-phenomenological exploration. According to Husserl, 'the task of phenomenology is to abstract structure and content of experience from the flow of consciousness, so that we may reflect on various forms of consciousness and their significance'[2]. The foundation of existentialism is the observation of the human struggle for freedom and the need to accept this struggle as an essential part of the human condition [3]. Existential phenomenology as a methodology is concerned with the experiences and actions of the individual as a subject to environmental influences, one who is also a purposeful being who has inner experiences and can interpret the meaning of his or her existence and relationship with others in a social world. Furthermore, existential phenomenology seeks to understand the everyday world of the individual. Thus, the vital role of phenomenology, in particular, is to describe meanings of social actions and the experiences of everyday life from the individual's (as subject) point of view [4].

As such, this research firstly explores and analyses the authentic feelings that the respondents experienced during and after the gubernatorial campaign and election, and how these impacted their thinking about the future of minority groups in Indonesia. Secondly, in the discussion, this research analyses the anxiety and alienation that have arisen through the lenses of Søren Kierkegaard and Karl Marx. Thirdly, this research tries to show that the feelings of alienation and anxiety have led them to apathy.

\section{Qualitative findings: anxiety, alienation, apathy}

All the respondents regarded BTP as an ideal-inspirational leader who was urgently needed by the country and in particular, Jakarta, the capital of Indonesia. Respondents described the existential challenges that arose within themselves, which deeply affected them. The findings are as follows:

\subsection{Sadness}

The first respondent is a worker in a university in Jakarta who expressed her heartfelt feelings after BTP's loss in the election in the following way: 
"I really really want BTP to be the governor in Jakarta so he can solve the problem of corrupt bureaucracy in this region. I was so sad and disappointed with the result of the election. I see that the majority of voters do not think about the long term development of this region. They only think about what they can get now. I feel sorry for BTP, but I believe his faith in God shows many things about himself."

Along with her sadness and disappointment, she complained about the decision of the voters who voted based on religious sentiment rather than reasonable considerations. According to her, BTP was the best candidate to address the complexities of Jakarta's development. This is the reason why she was so sad about the result.

\subsection{Anxiety and apathy}

The second respondent is female banker. She shares the same feelings as the first respondent, but she also feels intense anxiety that results in the feeling of resignation concerning her future political participation. The respondent remarks, "I was so disappointed with the result of the election. The result shows the irrationality of the voters in Indonesia because they do not vote based on the competencies of candidates. For this reason, I see there is no hope for an individual who shares a common background with $B T P$ to be the future leader in Jakarta. During the campaign, the feeling of worry rose in me since the rejection of BTP was very strong. I will never involve myself in political matters; I am better off resigning from any political participation."

The respondent felt that people's prejudice toward BTP's identity as Chinese-Christian was the prominent reason for his loss. The rejection of BTP is perceived as a rejection of people who have a similar background to BTP. This is the reason why she feels worried and anxious. Since BTP represents Chinese-Christians, the strong rejection is seen as a rejection of the Chinese-Christian community. This construct has led her to a state of apathy regarding any Chinese-Christian role in socio-political affairs.

The third respondent is a male worker in a multi-national company in Jakarta. He felt that because of the election, the stigma of Chinese-Christian as 'second-class' citizens has resurfaced. His remarks are as follows, "BTP is a man of integrity. I was so sad about the result, and I decided not to be involved in society anymore. However, I am a bit worried about the perception built on us as 'second-class' citizens in Indonesia. For that reason, I feel that maybe I do not really belong to this country."

In his response, the stigma of Chinese-Christians as second-class citizens is a worrying feeling. The anxiety was felt strongly after the loss of BTP. It is a dormant feeling that has accumulated from constant disappointments in his personal social experiences. This incident brings to the fore the feeling of social alienation resulting in a perception that one does not really belong to the country.

\subsection{Alienation and apathy}

The fourth respondent is a female worker in a multi-national company in Jakarta. She is impressed by BTP's leadership qualities. She remarks, "BTP is a loyal person with remarkable integrity. I feel so sad since BTP lost the election. For me, the background of BTP as a Chinese-Christian is the major issue here. BTP's loss affected me a lot, including deciding what I will do next, whether I will stay in Jakarta or move to another region that is more welcoming to me and my family. I do not want to be involved in social-political matters."

She has a similar response to the other respondents, but the event affected her even more deeply to the extent that she is considering moving out of Jakarta. In her 
understanding, the reason for BTP's loss is directly related to his minority background. Her response shows a feeling of alienation that has already been felt in the long term.

The fifth respondent is a worker in a specific bank in Jakarta. He predicted from the beginning that BTP would lose the election. His remarks were as follows,

"I had realized since the beginning that BTP would lose the election. It is because of BTP's background as a Chinese-Christian. Since I share a similar background to BTP, I do not want to be involved in politics. However, I am a bit worried about recent developments in Jakarta since there are radical groups that use religion, race, and ethnicity issues to pressurize minority groups. I feel hopeless about social-political affairs because we will always be second-class citizens in this country."

Through his responses, the respondent shows a feeling of anxiety about the situation in Jakarta. This anxiety arises because of the racial, ethnic and religious issues manipulated for political gains. He is concerned with his background as Chinese-Christian as the reason for not belonging to society. This feeling and experience - an accumulation of his experiences of repetitive smear campaigns - has led him to the feeling of alienation. He has resolved that no good will come from his involvement in political affairs.

This research shows that all the respondents underwent intense and emotional feelings during and after Jakarta's gubernatorial election. According to the responses, the research shows several phenomena: (i) The feeling of worry because others have rejected their existence as represented by BTP, (ii) The feeling of alienation since they are seen as second-class citizens, and (iii) The desire to withdraw from socio-political affairs because of social apathy. In what follows, these intense existential experiences will be interpreted from the lenses of philosophical exploration of anxiety, alienation, and apathy.

\section{Analysis: anxiety, alienation, apathy}

Anxiety is one of the central concepts in Søren Kierkegaard's philosophy. In one of his books, The Concept of Anxiety, it is explored through the phenomenon of phobias, in particular, the sense of catastrophic severance from one's relation to the foundation of life. In other words, this anxiety focuses on anything that comes along that causes extreme worry [5]. To Kierkegaard, there is the potential for anxiety to some degree in all individuals. The prominent reason for the emergence of anxiety is the uncertainty of the future in subject-object relations. In his view, each individual shares the same quality as "a subject" but not as "an object." If one thinks of the other person as an object while one is the subject "I," the relationship will become an unequal relationship where the subject will subordinate the other as an object. Only if we live in a "subject-subject relationship," then can we begin the process of eliminating prejudices, worries, and fears of others [6].

For Marx, the history of humankind has a double aspect: it is a history of increasing control of human beings over nature and at the same time, a history of the increasing alienation of human beings from other human beings. Alienation can be described as a condition in which humans are dominated by forces of their creation, which confront them as alien powers. To Marx, all major institutional spheres in a capitalist society, such as religion, the state, and political economy, are marked by a condition of alienation [7]. Marx sees the objectification as an instance of alienation. Just as humans, so long as they are engrossed in religion, can only objectify their essence as alien and fantastic beings, so, under the sway of egoistic needs, humans can only affirm themselves and produce objects in practice by subordinating their products and their activity to the domination of an alien entity, and by attributing to them the significance of an alien entity, namely money. Money is the alienated essence of social work and existence; the essence dominates them, and they worship it [8]. 
The notion of subject-object relation of Kierkegaard and objectification of Marx have something in common, i.e.; objectification is a source of problems in human relationships. The emergence of anxiety and alienation is forced into being by the objectification of humans by other humans or by forces beyond human beings (money, position, etc). This notion can be analyzed in the relationship between fellow human beings during the gubernatorial election in Jakarta in 2017. The racist designations that were attached to BTP - Chinese-Christian or a non-native citizen or second-class citizen - and his supporters, who were also Chinese-Christian, can easily be seen as the problem of objectification in the relation of humans within a social community.

Why is the discussion of this matter important? The feelings of anxiety and alienation are common feelings that any individual may encounter in society. Anxiety is mostly discussed in the field of psychology as a kind of mental problem, while for Kierkegaard, it relates to how the individual relates himself/herself to his/her world. Anxiety is rooted in how we as human beings form relations with others in this world. The anxiety of this kind cannot only be interpreted as depression but more fundamentally as an anticipation of what will happen in the future based on what is happening now [6]. The way the individual relates to the world defines distinctly what kind of world he/she experiences now and in the future. Therefore, anxiety can potentially arise in any individual.

On the other hand, discussion about alienation can be found in almost every culture, for example, in capitalistic societies, and within political matters. In Scarborough, Ontario, Joseph Sawan uses Marx's theory of alienation to examine social movements and promote social justice [9]. This paper combines the theory of anxiety and alienation to understand the socio-political decision of the Chinese-Christian minority in Jakarta during and after the 2017 gubernatorial election, which led the Chinese-Christian to a mood of apathy since the political identity is used to frame or patronize the minority group.

Living in a community where the relations are counted by number, i.e., majority and minority, the relationships among individuals will not be genuine and authentic because some individuals will become subjects (the majority) and others the object (the minority). This is an unequal relationship that should not exist within a healthy democratic society, which aims to foster equality and humanity. Furthermore, this situation will intensify the feeling of alienation since some human beings are objectified by other human beings as second-class citizens. In the end, it will also instill in individuals social apathy because they do not feel they belong to the society. This condition is exemplified by the fact that all respondents decided to withdraw from socio-political affairs because of the rejection of their existential identity during the Jakarta's gubernatorial election.

Through the responses of the respondents, we can see that during Jakarta's gubernatorial election, the disruption of identity was experienced again. In the past, the stigma of the Chinese as second-class citizens was played out as a political axiom. They were usually negatively referred to as nonpribumi in order to distinguish them from the pribumi (literally "sons of the soil") to put them at a political disadvantage, branded as people who should know their place [10]. This issue resurfaced again when BTP ran as one of the candidates for the governor post in Jakarta. Since the identity of BTP became the tool for political bullying, his supporters who share BTP's identity have been seen as 'alien' or nonpribumi, people who should know their place as a minority among a dominant majority. This situation causes the feeling of anxiety - following Kierkegaard - and the feeling of alienation - following Marx - and finally, the feeling of social apathy in the form of political withdrawal.

In order to extinguish such feelings, Marx suggests an emancipatory act by abolishing the act of objectification. With this emancipation, society will place everybody on the same level playing field based on equality and fairness [11]. Somewhat similarly to Marx, Kierkegaard suggests building a "subject-subject" relationship to replace the subject-object 
exploitation that is reflected in a dirty political campaign. For Kierkegaard, in order to build a genuine relationship, each individual - as subject "I" - has to see the other as another "Subject" beside oneself.

\section{Conclusion}

The goal of this article is to show that anxiety and alienation will disrupt existential identity and in turn, produce the social apathy that has resurfaced among Chinese-Christians. The disruption has resulted from a deep disappointment of losing the ideal leadership candidate who can represent their political aspirations because of a political smear campaign. The resolution to retreat into social apathy is taken as the last defense of an individual's identity since others have judged them as "alien" or the enemy. This condition can be a setback for the unity of Indonesia in which ethnic groups are constrained in 'a wall of prejudice' by others who see them through the lens of objectification. This situation may lead to a political 'crisis of trust' as the beginning of public friction. Only in this condition, can human society build an authentic and equal relationship in a just and democratic country.

\section{References}

1. E. Karensa. Ahok-Djarot Back on Top in Latest Approval Rating Survey. [Online] from http://jakartaglobe.id/news/ahok-djarot-back-on-top-in-latest-approval-ratingsurvey/ (2017).

2. W.D. Smith, Husserl, UK: Routledge (2007). https://philpapers.org/rec/WOOH-7

3. D. Langdridge, Phenomenological Psychology: Theory, Research and Method, UK: Pearson (2007). http://oro.open.ac.uk/8332/

4. J.S. Jun, Existential Phenomenology, The SAGE Dictionary of Qualitative Management Research, USA: SAGE, (2011). https://methods.sagepub.com/reference/thesage-dictionary-of-qualitative-management-research/n43.xml

5. S. Kierkegaard, The Concept of Anxiety: A Simple Psychologically Oriented Deliberation in View of the Dogmatic Problem of Hereditary Sin, A. Hannay [trans.], USA: W.W. Norton \& Company, (2014). p. 20-22. https://books.google.co.id/books?id=CG7nAgAAQBAJ\&lr

6. S. Kierkegaard, Works of Love, H.V. Hong, E. H Hong [trans.], USA: Princeton University Press (2009).

https://books.google.co.id/books/about/Works_of_Love.html?id=60EccL5znEC\&re dir_esc $=$ y

7. R.W. Schroeder, Continental Philosophy: A Critical Approach, USA: Blackwell Publishing. (2005). https://www.wiley.com/enus/Continental+Philosophy\%3A+A+Critical+Approach-p-x000428947

8. P. Smith, A. Riley, Culture Theory: An Introduction, USA: Blackwell Publishing, (2009), p. 38 https://www.wiley.com/enus/Cultural+Theory\%3A+An+Introduction\%2C+2nd+Edition-p-9781405169073

9. E.S. Joseph, Recovering Marx's Theory of Alienation: Theoretical Considerations from A Case Study With Community Activists in Scarborough, Ontario, A Canadian Journal of Work and Society, (2011), p. 17-18 http://www.justlabour.yorku.ca/volume17/pdfs/10_sawan_press.pdf

10. T. Yen-Ling, Spaces of Exclusion, Rethinking Chinese Exclusivity in Indonesia, in Indonesia Vol. 92, (2011). P. 127 https://www.jstor.org/stable/10.5728/indonesia.92.0125 
11. S. Roger, Marxism, The Palgrave Macmillan Dictionary of Political Thought, USA: Palgrave Macmillan, (2007), p. 27.

https://books.google.co.id/books?id=t9uGDAAAQBAJ\&dq 